
\title{
Peramalan Penjualan Daging Sapi Menggunakan Metode Trend Least Square
}

\author{
Cahya Rahmad \\ Program Studi Teknik Informatika, \\ Jurusan Teknologi Informasi, Politeknik \\ Negeri Malang \\ Malang, Indonesia \\ cahya.rahmad@polinema.ac.id
}

\author{
Rahmat Satrio Wibowo \\ Program Studi Teknik Informatika, \\ Jurusan Teknologi Informasi, \\ Politeknik Negeri Malang \\ Malang, Indonesia \\ wsatrio750@gmail.com
}

\author{
Dwi Puspitasari \\ Program Studi Teknik Informatika, \\ Jurusan Teknologi Informasi, \\ Politeknik Negeri Malang \\ Malang, Indonesia \\ dwi_sti@yahoo.com
}

\begin{abstract}
Hari®Zim beef shop in managing meat stock is not dynamic or not adjusted to the next sales forecast because it has not used a prediction system. Therefore it is necessary to have a system that can predict the sale of meat. In this study, the problem to be discussed is to test whether the time series forecasting model using the Trend Least Square method that will be used is in accordance with company conditions, so that Hari®Zim beef shop still exists in the face of similar business competition. This research was conducted using primary data in the form of beef sales data for the period of January 2015 May 2017 at Malang DayZim beef shop. System testing was carried out three times, each composition test using a different amount of training data. Then it will be compared with actual sales data to find out the best forecasting results and get the smallest forecasting error value with Mean Absolute Percentage Error (MAPE). The best estimation error was found in the third test using 9 months of training data and the MAPE calculation result was $0.022251(2 \%)$. Based on the results of system testing shows that the amount of data used affects the Mean Absolute Percentage Error (MAPE). The developed application can be recommended to determine the amount of the following month's stock at Hari®Zim beef shop.
\end{abstract}

Keywords-: mean absolute percentage error; sales forecasting; time series; trend least square

Abstrak- Selama ini toko daging sapi Hari®Zim dalam pengelolahan stok daging tidak dinamis atau tidak disesuaikan dengan perkiraan penjualan berikutnya karena belum menggunakan sistem prediksi. Oleh karena itu perlu adanya suatu sistem yang dapat memprediksi penjualan daging tersebut. Dalam penelitian ini, permasalahan yang akan dibahas adalah menguji apakah model peramalan time series dengan menggunakan metode Trend Least Square yang akan digunakan sudah sesuai dengan kondisi perusahaan, sehingga Toko daging sapi HarißZim tetap eksis dalam menghadapi persaingan usaha yang sejenis. Penelitian ini dilakukan dengan menggunakan data primer berupa data penjualan daging sapi periode Januari 2015 - Mei 2017 pada toko daging sapi Hari®Zim Malang. Pengujian sistem dilakukan tiga kali, masing-masing uji komposisi menggunakan jumlah data pelatihan yang berbeda. Kemudian akan dibandingkan dengan data penjualan aktual untuk mengetahui hasil peramalan terbaik dan mendapatkan nilai kesalahan peramalan terkecil dengan Mean Absolute Presentase Error (MAPE). Kesalahan perkiraan terbaik ditemukan pada tes ketiga dengan menggunakan data pelatihan 9 bulan dan di dapatkan hasil perhitungan MAPE sebesar 0,022251 (2\%). Berdasarkan hasil pengujian sistem menunjukkan bahwa jumlah data yang digunakan mempengaruhi Mean Absolute Presentase Error (MAPE). Aplikasi yang dikembangkan dapat di rekomendasikan untuk menentukan jumlah stok bulan berikutnya pada Toko daging sapi Hari®Zim.
Keywords - mean absolute presentase error; peramalan penjualan; time series; trend least square

\section{PENDAHULUAN}

Setiap perusahaan selalu membuat rencana kerja untuk menentukan target penjualan yang ingin dicapai kedepannya. Penentuan target penjualan berarti perusahaan berusaha untuk meramalkan penjualan kedepan dengan memperhatikan kondisi ke depan dan kondisi masa lampau [1].

Toko dan Supplier daging sapi Hari®Zim merupakan toko penjualan daging sapi di Malang yang juga seperti perusahaan lainnya membuat target penjualan. Namun selama ini penentuan target ke depan tidak obyektif karena hanya berdasarkan intuisi manajemen saja. Dalam penentuan target masih dipengaruhi oleh pendapat atau perasaan orang yang membuatnya. Target yang ditetapkan sering kali tidak sesuai dengan data penjualan aktual sehingga mempengaruhi seluruh perencanaan selanjutnya dan pertanggungjawaban kepada atasan. Untuk itu diperlukan suatu alat yang dapat membantu manajemen memutuskan target penjualan ke depan dengan lebih objektif. Adapun metode peramalan yang digunakan adalah metode kuadrat terkecil (Least Square) yang merupakan model peramalan time series dengan memperhatikan data yang disusun berdasarkan urutan waktu penjualan di masa lampau. Penelitian ini bertujuan untuk mengestimasi tingkat penjualan daging sapi periode yang akan datang.

Bagaimana meramalkan tingkat penjualan daging sapi periode yang akan datang pada Toko dan Supplier daging sapi Hari®Zim di Malang menggunakan metode Least Square. Mengetahui tingkat penjualan daging sapi untuk periode yang akan datang pada Toko dan Supplier daging sapi Hari®Zim di Malang dengan metode Least Square [2].

\section{PERAMALAN TREND LEAST SQUARE}

Toko dan supplier daging sapi Hari®Zim berdiri pada tahun 2012 tepatnya di Jalan Lowokdoro gang 3 Kota Malang. Saat itu toko Hari®Zim masih menjual 4 jenis daging sapi yaitu serloin, tenderloin, gandik dan iga potong. Seiring dengan berjalannya waktu dan permintaan pembeli semakin banyak jenis daging yang dibutuhkan, toko Hari®Zim mulai menambah berbagai jenis daging pada stok penjualannya, dari yang awalnya hanya 4 jenis daging sapi, pada tahun 2017 jumlah jenis daging sapi yang di jual pada toko Hari®Zim kini terdapat 17 jenis daging sapi.

Peramalan (forecasting) adalah seni dan ilmu memprediksi peristiwa-peristiwa yang akan terjadi dengan menggunakan 
data historis dan memproyeksikannya ke masa depan dengan beberapa bentuk model matematis. Untuk melakukan peramalan diperlukan metode tertentu dan metode mana yang digunakan tergantung dari data dan informasi yang akan diramal serta tujuan yang hendak dicapai [3].

Terdapat dua pendekatan untuk melakukan peramalan yaitu dengan pendekatan kualitatif dan pendekatan kuantitatif. Metode peramalan kualitatif digunakan ketika data historis tidak tersedia. Metode peramalan kualitatif adalah metode subyektif (intuitif). Metode ini didasarkan pada informasi kualitatif. Dasar informasi ini dapat memprediksi kejadiankejadian di masa yang akan datang. Keakuratan dari metode ini sangat subjektif[4].

Metode peramalan kuantitatif dapat dibagi menjadi dua tipe, causal dan time series. Metode peramalan causal meliputi faktor-faktor yang berhubungan dengan variabel yang diprediksi seperti analisis regresi. Peramalan time series merupakan metode kuantitatif untuk menganalisis data masa lampau yang telah dikumpulkan secara teratur menggunakan teknik yang tepat. Hasilnya dapat dijadikan acuan untuk peramalan nilai di masa yang akan datang[5].

Peramalan penjualan adalah suatu prakiraan atas ciri-ciri kuantitatif dan kualitatif termasuk dari perkembangan pasaran dari suatu produk yang di produksi oleh suatu perusahaan, pada suatu jangka waktu tertentu dimasa yang akan datang [6].

Prinsip dari metode kuadrat terkecil adalah meminimumkan jumlah kuadrat penyimpangannya (selisih) nilai variabel bebasnya (Yi) dengan nilai trend / ramalan $\left(Y^{\prime}\right)$ atau $\Sigma\left(Y i-Y^{\prime}\right)^{2}$ diminimumkan.

Dengan bantuan kalkulus yaitu deviasi partial, $\Sigma\left(Y i-Y^{\prime}\right)^{2}$ diminimumkan maka akan diperoleh dua buah persamaan normal sebagai berikut:

$$
\begin{array}{r}
\Sigma Y i=n . a+b . \Sigma X i \\
\Sigma X i Y i=a . \Sigma X i+b \cdot X i^{2} \ldots \ldots . .
\end{array}
$$

Dengan menyelesaikan kedua persamaan normal ini secara simultan, maka nilai $a$ dan $b$ dari persamaan trend $Y^{\prime}=a+b X$ yang dicari dapat dihitung. Agar perhitungan menjadi lebih sederhana pemberian kode pada nilai $X$ (tahun) diupayakan sedemikian rupa sehingga $\Sigma X i=0$, dengan begitu persamaan normal di atas dapat disederhanakan menjadi:

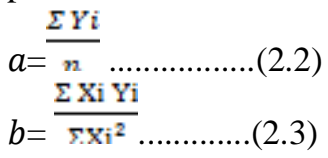

Setelah nilai $a$ dan $b$ dihitung dengan rumus di atas maka persamaan nilai trend liniernya dapat disusun sebagai berikut:

$Y=a+b X$

$Y=$ nilai trend pada periode tertentu

$a=$ intersep yaitu besarnya nilai $Y$ bila nilai $X=0$

$b=$ slope garis trend, yaitu perubahan variabel $Y$ untuk setiap perubahan satu unit variabel $X$

$X=$ periode waktu

Untuk membuat nilai $\Sigma X i=0$ tergantung dari jumlah data tahunnya yaitu genap dan ganjil, pedomannya sebagai berikut: (Budiasih Yanti, 2012)

(1.) Bila jumlah data tahun tidak habis dibagi dua yaitu ganjil maka dipakai skala $\mathrm{x}=1$ tahun. Maka tahun dasar diletakkan pada tahun yang ditengah, misalnya sebagai berikut:

Tabel 2.1 Skala $X$ data ganjil

\begin{tabular}{|l|l|l|l|l|l|l|l|}
\hline Bulan & Jan & Feb & Mar & Apr & Mei & Jun & Jul \\
\hline $\mathrm{x}$ & -3 & -2 & -1 & 0 & 1 & 2 & 3 \\
\hline
\end{tabular}

(2.) Bila jumlah data tahun habis dibagi dua yaitu genap maka dipakai skala $\mathrm{x}=1 / 2$ tahun. Maka tahun dasar diletakkan pada tahun yang ditengah, misalnya sebagai berikut:

Tabel 2.2 Skala $X$ data genap

\begin{tabular}{|l|l|l|l|l|l|l|l|l|}
\hline Bulan & $\mathrm{Ja}$ & $\mathrm{Fe}$ & $\mathrm{Ma}$ & $\mathrm{Ap}$ & $\mathrm{Me}$ & $\mathrm{Jn}$ & $\mathrm{Jl}$ & $\mathrm{Ag}$ \\
\hline $\mathrm{x}$ & -7 & -5 & -3 & -1 & 1 & 3 & 5 & 7 \\
\hline
\end{tabular}

\section{A. Analisis Sistem}

\section{METODE}

Berdasarkan hasil wawancara dengan pihak manajemen Toko dan Supplier daging sapi Hari ${ }^{\circledR}$ Zim, perusahaan selalu membuat rencana terget penjualan, namun selama ini perusahaan memperkirakan penjualan kedepan hanya berdasarkan intuisi manajemen yang masih dipengaruhi pendapat dan perasaan pembuatnya. Sehingga target yang ditetapkan sering tidak sesuai dengan perencanaan sehingga mempengaruhi seluruh perencanaan selanjutnya dan pertanggungjawaban kepada atasan.

\section{B. Hasil Analisis}

Hasil analisis masalah selama ini dalam memperkirakan target penjualan ke depan tidak objektif karena hanya mengandalkan intuisi manajemen saja. Target yang ditetapkan sering kali tidak sesuai dengan penjualan aktual.

Sistem yang akan dibangun ditujukan untuk digunakan pihak manajemen sehingga dapat membantu pihak manajemen perusahaan dalam menentukan target berdasarkan data-data penjualan yang sebelumnya. Dengan demikian penentuan target dapat lebih dipertanggungjawabkan dan lebih berdasar.

\section{Perancangan Sistem}

\section{C.1. Diagram Konteks / Context Diagram}

Aplikasi peramalan pada umumnya memiliki fitur managemen data dan melakukan perhitungan peramalan. Sistem memberikan beberapa fitur untuk digunakan oleh pengguna dalam mengelola data.

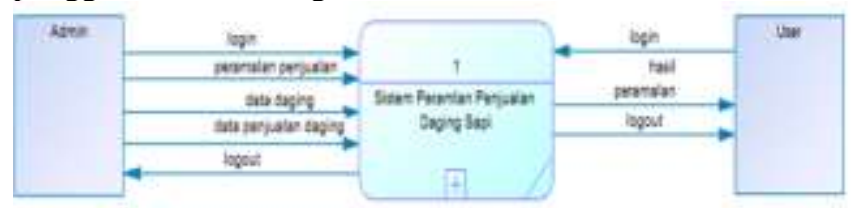

\section{2 DFD Level 1}

\section{Gambar 1. Context Diagram}

DFD Level 1 digunakan untuk menggambarkan alur tujuan data yang akan diproses, DFD Level 1 ini digunakan untuk menggambarkan sistem secara umum pengambaran sederhana dari aplikasi ini. 


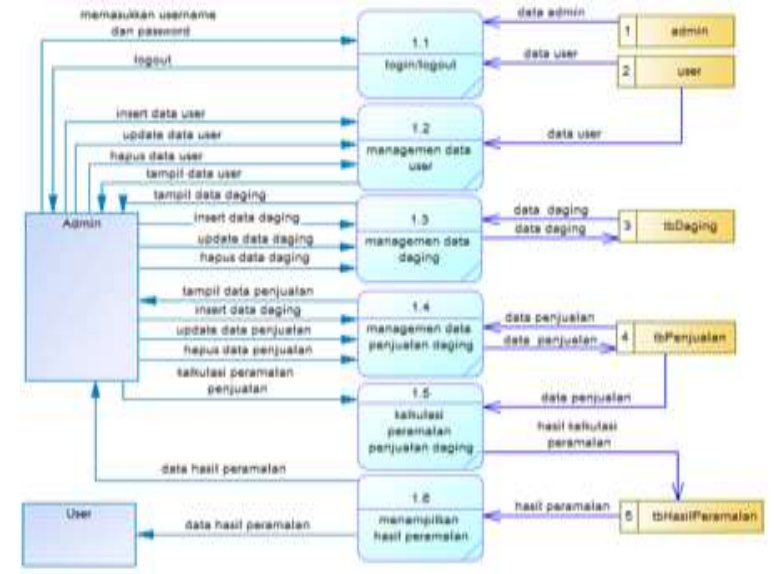

Gambar 2. DFD Level 1

Gambar 2 menjelaskan bahwa sistem memiliki 6 proses utama yaitu proses login/logout, proses managemen data user, proses managemen data daging, proses managemen data penjualan daging, proses kalkulasi peramalan penjualan daging, dan proses menampilkan hasil peramalan. Admin bisa mengelola data daging dan penjualannya. Untuk melakukan perhitungan peramalan dibutuhkan data penjualan. Sedangkan proses menampillkan hasil peramalan yaitu admin dan user bisa melihat hasil perhitungan peramalan yang telah dilakukan.

\section{C.3. DFD Level 2 Managemen Data Penjualan}

Pada DFD level 2 ini menjelaskan tentang prosesproses yang terdapat pada pengolahan data penjualan. DFD level 2 managemen data penjualan memiliki proses simpan penjualan daging, update data penjualan daging, hapus penjualan data daging dan tampilkan data penjualan yang tersimpan.

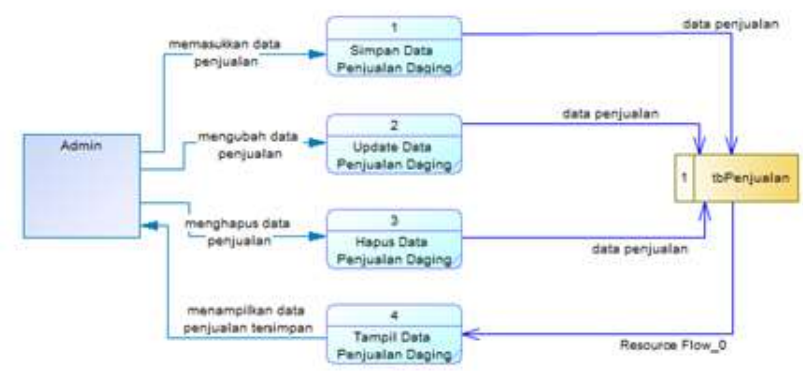

Gambar 3 DFD Level 2 Managemen Data Penjualan C.4. DFD Level 2 Kalkulasi Peramalan Penjualan

Pada DFD level 2 ini menjelaskan tentang prosesproses yang terdapat pada kalkulasi peramalan penjualan. DFD level 2 kalkulasi peramalan penjualan memiliki proses kalkulasi peramalan penjualan, simpan hasil peramalan, dan tampil hasil peramlan yang tersimpan.

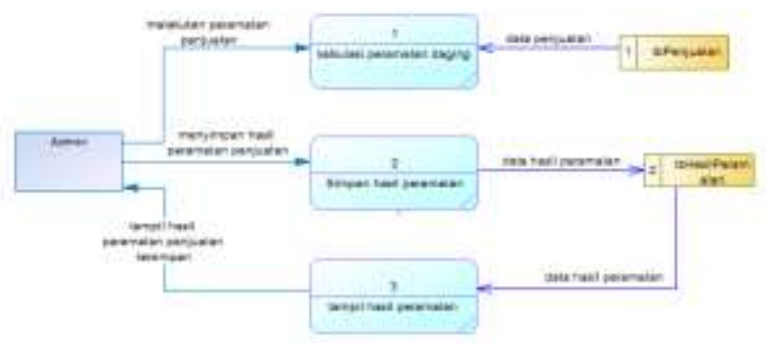

Gambar 4 DFD Level 2 Kalkulasi Peramalan Penjualan

\section{HASIL DAN PENGUJIAN}

A. Implementasi

Implementasi ini merupakan penerapan aplikasi dari analisa dan rancangan sistem yang telah dibuat sebelumnya. Dari implementasi ini akan dapat dipahami jalannya aplikasi sistem klasifikasi kecenderungan penyelesaian studi ini.

\section{B. Implementasi Least Square Method}

Dalam proses metode least square ini tentukan jumlah $n$ (jumlah periode/bulan) dan banyaknya pasangan data yang digunakan dalam peramalan sebagai periode dasar.

Setelah menentukan banyak data yang digunakan kemudian mencari nilai $\mathrm{X}, \mathrm{X} 2, \mathrm{XY}$ untuk dasar mencari trend seperti berikut.

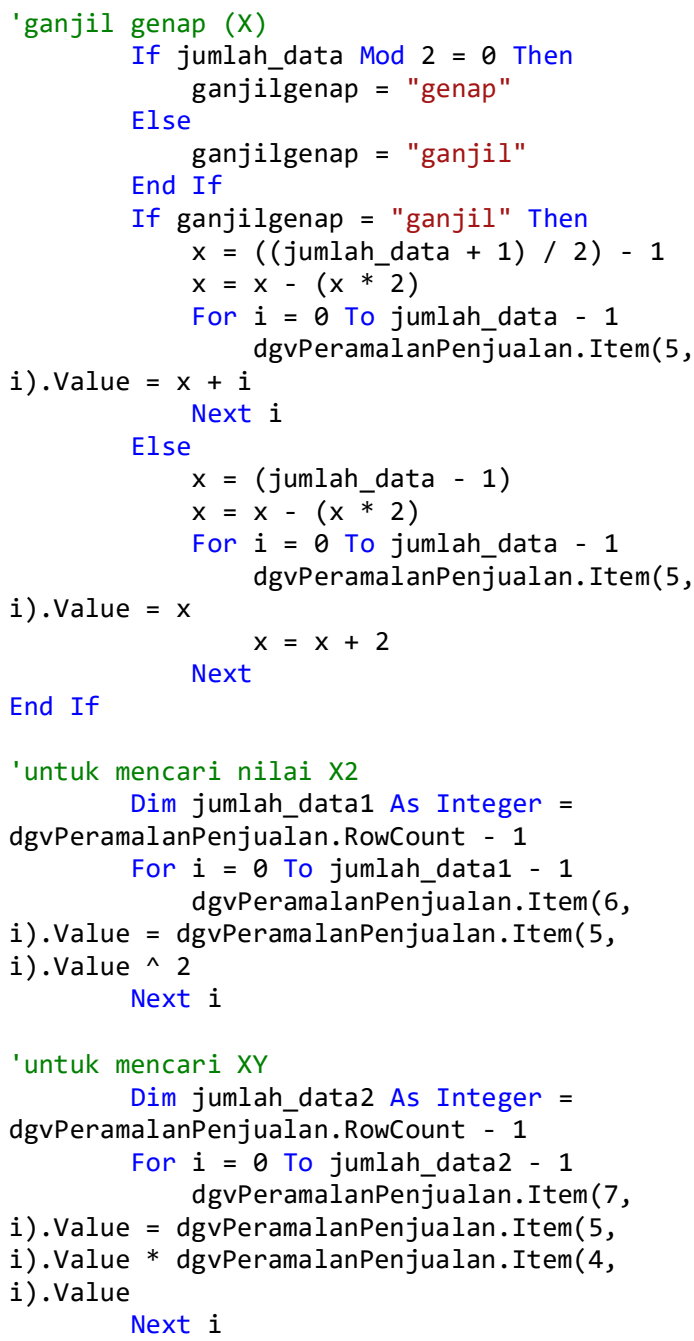

Gambar 5 Proses Perhitungan X, X2,XY

Proses selanjutnya adalah mencari nilai $a$ (besar nilai trend) dan menghitung $b$ (perubahan nilai trend) terhadap $X$ (waktu) kemudian hitung persamaan trend $(\mathrm{Y}=\mathrm{a}+\mathrm{bX})$.

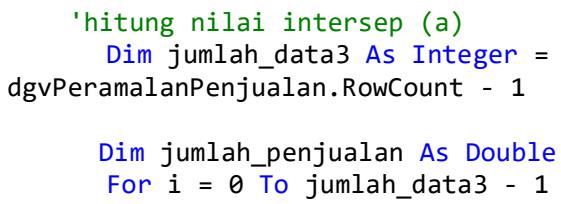




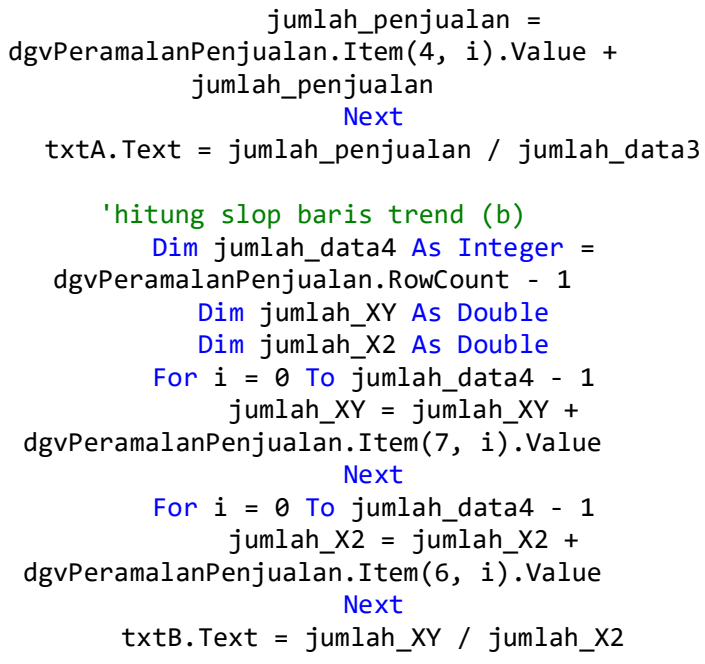

'hasil ramal menggunakan metode trend least square Dim Max As Integer $=0$

Dim BulanNext As String Dim tahun As Integer

For Each rws As DataGridViewRow In dgvPeramalanPenjualan. Rows

If Max < rws.Cells( $\theta)$. Value Then Max = rws.Cells( $(\theta)$. Value

Next

Dim jumlah data5 As Integer =

dgvPeramalanPenjualan. RowCount - 1

Dim nilai peramalan As Double

nilai_peramalan $=$ txtA. Text $+($ txtB. Text $*$ (jumlah_data5 + 1))

txtHasilRamal. Text = nilai_peramalan

Gambar 6. Proses Perhitungan Nilai Trend

\section{Pengujian Sistem}

\section{C.1 Menu Utama}

Pada menu utama ini divisi penjualan dapat memasukkan data aktual baru pada pilihan tambah data daging.

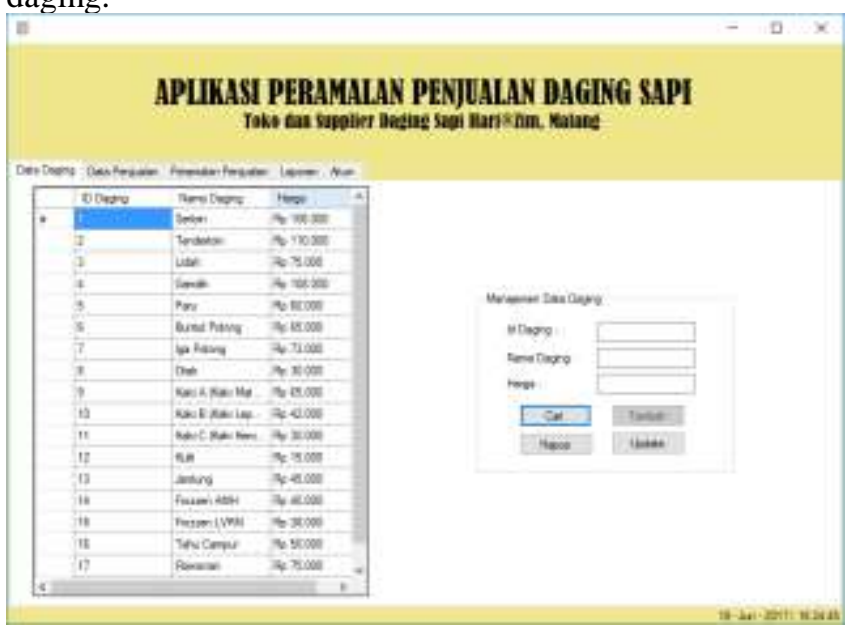

Gambar 7. Halaman Tambah Data Daging

Selanjutnya admin bisa memasukkan data aktual baru pada pilihan tambah data penjualan.

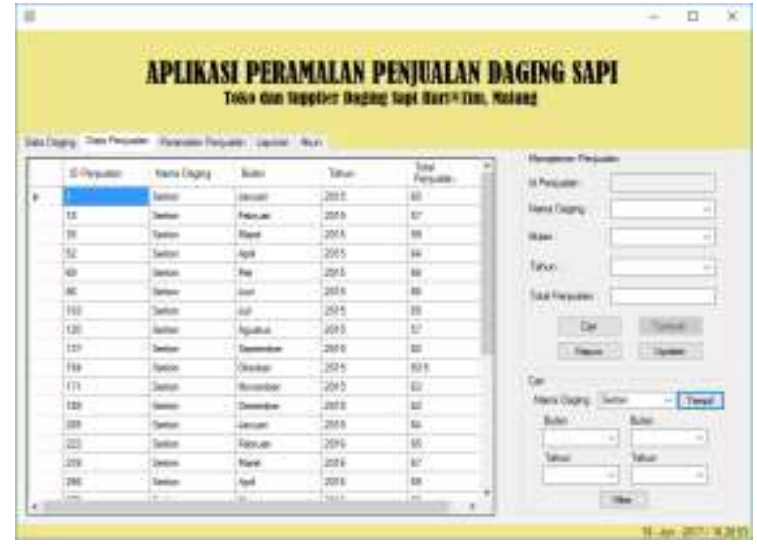

Gambar 8. Halaman Tambah Data Penjualan

\section{C.2 Menu Forecast}

Menu forecast untuk melakukan perhitungan peramalan menggunakan metode Least Square untuk satu periode/bulan selanjutnya atau melakukan pengujian peramalan satu tahun dengan jumlah data periode tertentu yang digunakan klik tombol 'Ramal' sesuai pilihan.

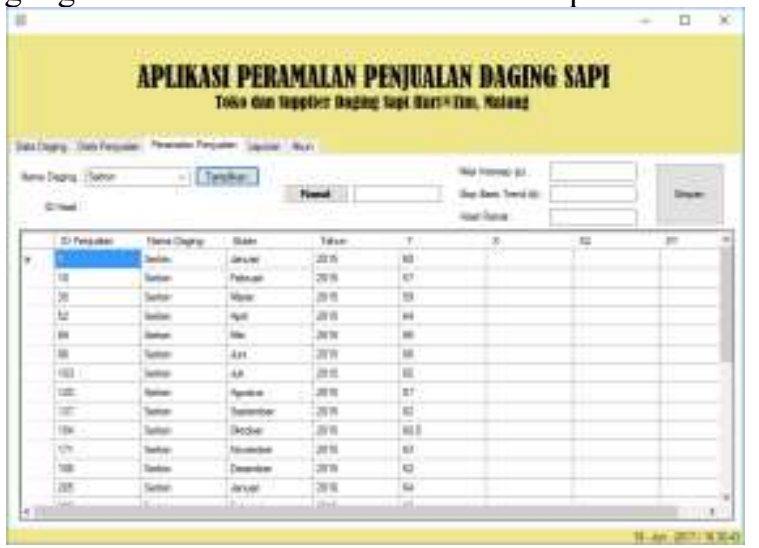

\section{Gambar 9 Halaman Forecast}

C.3 Form Hasil Peramalan

Form hasil peramalan menampilkan hasil peramalan dan tabel detail perhitungan Least Square. Pada gambar berikut adalah tampilan hasil peramalan untuk satu periode kedepan.

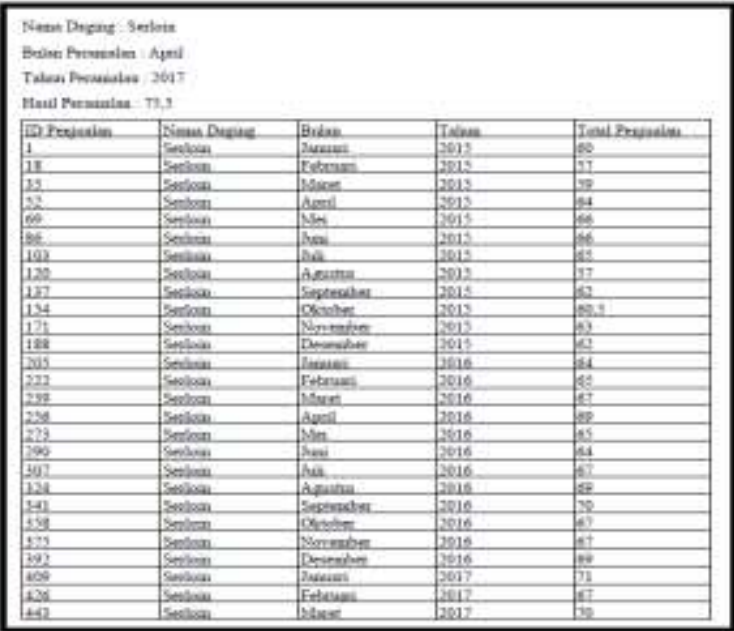

Gambar 10 Halaman hasil peramalan C.4 Form Pengujian 
Pada gambar 11 berikut adalah tampilan halaman hasil pengujian peramalan data 9 bulanan untuk meramalkan penjualan pada bulan april tahun 2017. Pada halaman ini berisi tabel perhitungan pengujian kesalahan peramalan (MAPE) sesuai pilihan data yang digunakan pada halaman pengujian sebelumnya.

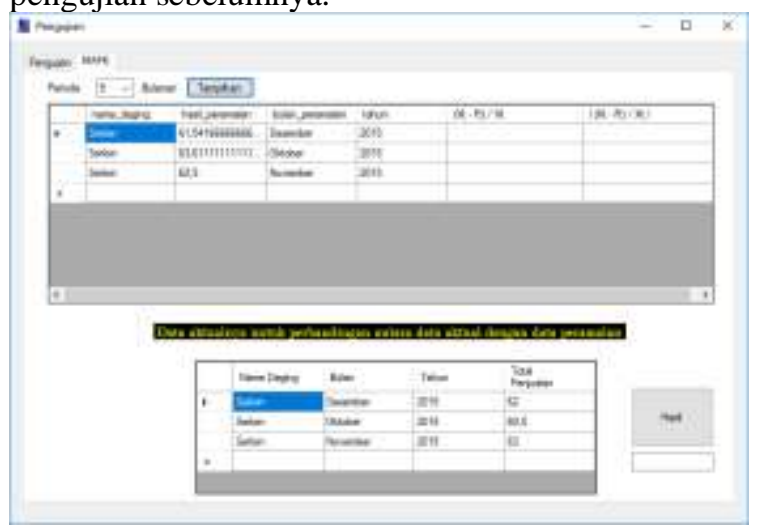

Gambar 11 Halaman Pengujian (MAPE)

D. Analisa Hasil Pengujian Sistem

Pengujian bulanan akan dilakukan untuk membandingkan forecast penjualan dengan jumlah periode penjualan tertentu yang digunakan. Kemudian akan disandingkan dengan data penjualan aktual untuk mengetahui hasil forecast dengan menggunakan jumlah periode manakah yang terbaik dan yang memperoleh nilai kesalahan peramalan Mean Absolut Presentase Error (MAPE) terkecil. Data acuan yang digunakan untuk pengujian adalah data bulan januari 2015 sampai desember 2015 untuk meramalkan bulan januari 2016 hingga desember 2016. Pada pengujian ini dilakukan 3 tahapan pengujian dengan kriteria yaitu, pengujian 1 menggunakan data 3 bulanan, pengujian 2 menggunakan data 6 bulanan dan pengujian 3 menggunakan data 9 bulanan.

\section{E. Keberhasilan}

Pengujian bulanan dilakukan untuk mendapatkan hasil peramalan dengan nilai kesalahan peramalan $M A P E$ terkecil dalam proses peramalan berdasarkan jumlah data periode yang berbeda. Hasil kesalahan peramalan keempat pengujian tersebut dapat dilihat pada tabel berikut.

Tabel 4.1 Perbandingan Kesalahan Peramalan (MAPE)

\begin{tabular}{|c|c|c|c|}
\hline & Pengujian 1 & Pengujian 2 & Pengujian 3 \\
\hline MAPE & 0,018181 & 0,043071 & 0,022251 \\
& $(2 \%)$ & $(4 \%)$ & $(2 \%)$ \\
\hline
\end{tabular}

Berdasarkan pengujian bulanan yang telah dilakukan didapatkan hasil bahwa pengujian terakhir dengan data 9 bulanan menghasilkan kesalahan peramalan paling kecil dibandingkan dengan pengujian lainnya. Hal ini menunjukkan bahwa data periode yang digunakan dalam peramalan akan sangat berpengaruh terhadap tingkat kesalahan peramalan.

\section{KESIMPULAN}

Metode peramalan Least Square ini dapat diimplementasikan untuk studi kasus penjualan daging sapi pada Toko dan Supplier daging sapi Hari ${ }^{\circledR}$ Zim Malang.

Aplikasi ini dapat melakukan perhitungan peramalan dengan cukup baik jika jumlah data yang digunakan dalam proses peramalan semakin banyak, sehingga kesalahan peramalan atau error yang dihasilkan semakin rendah. Hal ini dibuktikan pada pengujian dengan menggunakan jumlah periode yang paling banyak yaitu per 9 bulan dan menghasilkan error Mean Absolut Presentase Error (MAPE) sebesar 0,066752122 (2\%) lebih rendah jika dibandingkan dengan hasil uji pada pengujian yang jumlah datanya lebih sedikit.

Diharapkan adanya penelitian dengan metode trend linier lain seperti Semi Average Method dan Moving Average Method untuk kemudian dibandingkan dengan metode Least Square ini.

\section{REFERENSI}

[1] F. R. Hariri, "Metode Least Square Untuk Prediksi Penjualan Sari Kedelai Rosi,” vol. 7, no. 2, pp. 731-736, 2016.

[2] Y. A. Kurniawan and B. Nurhadiyono, "Komparasi Metode Least Square Dan Double Exponential Smoothing Untuk Menganalisis Pendapatan Retribusi Uji Kendaraan Bermotor," pp. 1-8, 2016.

[3] A. Nurlifa and S. Kusumadewi, "Sistem Peramalan Jumlah Penjualan Menggunakan Metode Moving Average Pada Rumah Jilbab Zaky," J. INOVTEK POLBENG, 2017.

[4] M. Rahmawita and I. Fazri, "Aplikasi Peramalan Penjualan Obat Menggunakan Metode Least Squaredi Rumah Sakit Bhayangkara," vol. 4, no. 2, pp. 201-208, 2018.

[5] D. P. Pamungkas, "Implementasi Metode Least Square Untuk Prediksi Penjualan Tahu Pong," vol. 2, no. 2, pp. 75-81, 2016.

[6] R. B. Septiawan and E. Z. Astuti, "Perbandingan Metode Setengah Rata-Rata Dan Metode Kuadrat Terkecil Untuk Peramalan Pendapatan Perusahaan Di Blu Uptd Terminal Mangkang," vol. 15, no. 2, pp. 132139, 2016.

[7] Assauri, Sofyan, 1999. Manajemen Produksi dan Operasi, Hal.139, Edisi Revisi, LPFE-UI, Jakarta (diakses pada 11 Februari 2017)

[8] Erlina. 2012. Peramalan Anggaran Penjualan. Jurnal Ekonomi Universitas Sumatera Utara. (diakses pada 11 Februari 2017)

[9] Rahayu, Indayah. 2016. Peramalan penjualan beras menggunakan metode moving average. https://simki.unpkediri.ac.id/mahasiswa/file_artikel/2016/11.1.03.03.01 27.pdf (diakses pada 11 Februari 2017)

[10]Rahmawati, Noviana. 2013. Forecasting Penjualan Sepeda Motor Kawasaki. Tugas Akhir Fakultas Ekonomi Universitas Negeri Yogyakarta.

http://eprints.uny.ac.id/17905/1/Tugas\%20Akhir.pdf.(diakses pada 11 Februari 2017) 